Альма-матер, 2011. - $256 \quad$ с. - Режим доступу: http://pidruchniki.com/19720822/sotsiologiya/klasifikatsiyi_dityachih_molodizhnih_organizatsiy

7. Про АПОС [Електронний ресурс]. - Режим доступу : http://profkom.info/main/about.html

8. Про НСС [Електронний ресурс]. - Режим доступу : http://nss.org.ua/pro-nss

9. Український молодіжний форум : повний перелік учасників [Електронний ресурс].Режим доступу : http://fri.net.ua/node/1464

\title{
References
}

1. Birkenbil M. Molitvennik dlya shefa / M. Birkenbil // Preuspevat s radostyu. Molitvennik dlya sheaf : per. s nem. / N. Enkelmann, M. Birkenbil. - M. : SP "Interekspert" ; Ekonomika, 1999. - S. 269-394.

2. VMGO Students'ka respublika [Elektronnyj resurs]. - Rezhym dostupu : http : //studrespublika.com/vmgo.php

3. Volkova N. P. Pedagogika : posib. dlya studentiv VNZ / N. P. Volkova. - Kyiv : Akademija, 2003. $-576 \mathrm{~s}$.

4. Pro molodizhni ta dytjachi gromads'ki organizacii' : Zakon Ukrai'ny [Elektronnyj resurs] // Vidomosti Verhovnoi' Rady Ukrai'ny (VVR). - 1999. - № 1. - Rezhym dostupu : http: //zakon3.rada.gov.ua/laws/show/281-14

5. Istorija asociacii' [Elektronnyj resurs] // Ukrai'ns'ka asociacija students'kogo samovrjaduvannja. - Rezhym dostupu : http://www.-uass.org.ua/index.php/about/history

6. Lisovec' O. V. Klasyfikacii' dytjachyh ta molodizhnyh organizacij [Elektronnyj resurs] / O. V. Lisovec' // Teorija i metodyka roboty z dytjachymy ta molodizhnymy organizacijamy Ukrai'ny. - Kyiv : Al'ma-mater, 2011. - $256 \mathrm{~s}$. - Rezhym dostupu : http://pidruchniki.com/19720822/sotsiologiya/klasifikatsiyi_dityachih_molodizhnih_organizatsiy

7. Pro APOS [Elektronnyj resurs]. - Rezhym dostupu : http://profkom.info/main/about.html

8. Pro NSS [Elektronnyj resurs]. - Rezhym dostupu : http://nss.org.ua/pro-nss

9. Ukrai'ns'kyj molodizhnyj forum : povnyj perelik uchasnykiv [Elektronnyj resurs]. - Rezhym dostupu : http://fri.net.ua/node/1464

K. G. Trybulkevych YOUTH ORGANIZATIONS AND SUBCULTURES IN THE UKRAINIAN INDEPENDENT STATE: POTENTIAL INFLUENCE ON STANDING LEADER'S PERSONALITY

The article is devoted to the analysis of the functioning of youth organizations and subcultures from 1991 to the present. The potential of the influence of youth activity on the formation of the person of the student leader is determined. The activity is grounded as a way of human existence, the ability to make certain changes in the environment and the self, the dependence of changes in personality development on its needs, the purpose, means of its realization and the result of activity.

Establishing analytical-synthetic links between the essence of rights, the main causes and consequences of their violation, promotes the formation of knowledge of basic rights and freedoms, the ability to protect their rights and freedoms and rights of another person. The high level of leadership skills is characterized by deep, solid knowledge of key leadership skills, such as: goal-setting, the ability to accept complex controversial decisions; reflexive analysis skills; the ability to defend their rights and freedoms and the rights and freedoms of others, to speak to a large audience, to master stress, to effectively engage in interpersonal interaction.

Implementation of youth activity in student self-government bodies, constructive activities of youth organizations, ensures the formation of the leader's personality and is a prerequisite for the democratic foundations of the state's formation.

Key words: youth organizations, public organizations, subcultures, student self-government, student, youth, activity, leader.

УДК 159.922.73:159.9.019.4

I. С. ХОМИч

DOI: https://doi.org/10.35619/prap_rv.vi12.78

\section{ОСОБЛИВОСТІ СОЦІАЛЬНО-ПСИХОЛОГІЧНОЇ КОМПЕТЕНТНОСТІ МОЛОДШИХ ШКОЛЯРІВ У СФЕРІ НОРМОВІДПОВІДНОСТІ ВЛАСНОЇ ПОВЕДІНКИ}

Стаття присвячена дослідженню рівня розвитку сочіально-психологічної компетентності школярів у сфері нормовідповідності власної поведінки залежно від їхньої статі, віку, соиіально- 
економічного статусу сім'ї та соиіометричного статусу в класі. За допомогою співвідношення стадій розвитку моральних суджень молодших школярів за методикою Л. Колберга з одного боку, $i$ рівнів розвитку уявлень про нормовідповідність власної поведінки на основі показників експертного опитування - з іншого, ми отримали інтегральний емпіричний показник - рівень розвитку сочіальнопсихологічної компетентності досліджуваних у сфері нормовідповідності власної поведінки та дослідили особливостів заємозв 'язку між рівнем розвитку соціально-психологічної компетентності молодших школярів у сфері нормовідповідності власної поведінки та показниками їх статі, віку, соиіального статусу сім'ї та соціометричного статусу в класі.

Ключові слова: молодший школяр, моральні судження, соціально-психологічна компетентність, нормовідповідність поведінки, стать, вік, сочіально-економічний статус сім' $і$, соиіометричний статус у класі.

Статья посвящена исследованию различий уровня развития социально-психологической компетентности школьников в сфере соответствия собственного поведения нравственным нормам в зависимости от их пола, возраста, сочиально-экономического статуса семьи и сочиометрического статуса в классе.С помощью соотношения стадий развития моральных суждений младших школьников по методике Л.Колберга с одной стороны, и уровней развития представлений о соответствии собственного поведения нравственным нормам на основании показателей экспертного опроса - с другой, мы получили эмпирический показатель - уровень развития социально-психологической компетентност ииспытуемых в сфере соответствия собственного поведения нравственным нормам и исследовали особенности взаимосвязи между уровнем развития сочиально - психологической компетентности младших школьников и показателями их пола, возраста, социального статуса семьи и сочиометрического статуса в классе.

Ключевые слова: младший школьник, моральные суждения, нормосоответствие поведения, сочиально-психологическая компетентность, пол, возраст, социально-экономический статус семьи,сочиометрический статус класса .

Постановка проблеми.У наш непростий час актуальною залишається проблема моральних аспектів поведінки молодших школярів. Отже, проаналізуємо основні закономірності, отримані в рамках вивчення взаємозв'язку між рівнем розвитку соціально-психологічної компетентності молодших школярів у сфері нормовідповідності власної поведінки та показниками їх статі, віку, соціального статусу сім'ї та соціометричного статусу в класі.

Аналіз останніх досліджень і публікацій. Нормовідповідна поведінка дитини визначається моральною вихованістю, показниками якої є моральні якості особистості, що формуються через усвідомлене засвоєння нею певних знань про норми моралі. Формування соціально-психологічної компетентності у сфері нормовідповідності власної поведінки є необхідною умовою морального розвитку особистості в цілому. Для молодших школярів важливим новоутворенням $є$ «внутрішня позиція», яка являе собою більш усвідомлене ставлення до себе, до інших людей, подій, вчинків і виявляється в тому, «що у свідомості дитини виділяється система моральних норм, яким вона слідує чи намагається слідувати завжди і скрізь, незалежно від обставин, які склалися» (Г.А. Мішакова) [5, с.52]. На думку В.С.Мухіної, «...у психології встановлено, що розвиток моральних почуттів відбувається в результаті «переселення всередину» нормативних знань і тих моральних почуттів, які виникають у дитини під впливом оцінки з боку дорослого» [6, с.312]. За О.В. Скрипченко [10], у віці від 6 до 10 років відбувається інтенсивний моральний розвиток завдяки активному накопиченню дитиною досвіду соціальної поведінки. Отже, розвиток соціально-психологічної компетентності дитини у сфері нормовідповідності власної поведінки починається в молодшому шкільному віці і залежить від правильності побудови 3 нею стосунків, завдяки яким вона отримує досвід відповідальної поведінки. Учні 1-х і більшість учнів 2-х класів найчастіше не здатні до повноцінної саморегуляції, тоді як школярі, що навчаються в третьому і четвертому класах, в змозі управляти собою, своїми почуттями і поведінкою. Цієї думки дотримується Р.В. Павелків, підкреслюючи, що учням 1-х класів ще важко усвідомити мотиви власних вчинків, тоді як для більшості учнів 2-3-х класів це вже доступно [8]. Отже, описані вище вікові зміни свідчать про значне зростання здатності молодшого школяра до більш складних форм взаємодіїі 3 соціальним оточенням на основі підвищення соціально-психологічної компетентності у сфері нормовідповідності власної поведінки. Підтримуємо думку Д.С. Порохняк про те, що необхідною умовою морального розвиткудітей $\epsilon$ розвиток моральних якостей особистості, почуттів і накопичення досвіду моральної поведінки [9].

Формулювання цілей статті. Метою нашого повідомлення є дослідження рівня соціальнопсихологічної компетентності молодших школярів у сфері нормовідповідності власної поведінки Випуск 12, 2019. Збірник наукових праць РДГУ 
залежно від їхньої статі, віку, соціально-економічного статусу сім'ї та соціометричного статусу в класі. Актуальність нашої роботи зумовлена фундаментальністю проблеми морального розвитку та виховання молодших школярів, адже саме завдяки високому рівню соціально-психологічної компетентності учнів у сфері нормовідповідності власної поведінки соціально необхідні вимоги суспільства перетворюються у внутрішні стимули особистості дитини. Згідно із сформульованою метою нашими завданнями $є$ : аналіз останніх публікацій із проблематики нашої роботи, опис методів дослідження з метою конкретизації дослідницької позиції та здійснення емпіричного дослідження рівня розвитку соціально-психологічної компетентності школярів у сфері нормовідповідності власної поведінки залежно від їхньої статі, віку, соціально-економічного статусу сім'ї та соціометричного статусу в класі.

Виклад основного матеріалу. Дослідження проводилось на базі Рівненської гімназії «Гармонія», Рівненської класичної гімназії «Престиж» (м. Рівне), Луцьких загальноосвітніх шкіл I-III ступенів №5 і №8 (м. Луцьк) та Тернопільської загальноосвітньої школи I-III ступенів №19 (м. Тернопіль). Досліджуваними стали учні перших-четвертих класів у кількості 189 осіб. Дослідницький контингент було диференційовано за критеріями статі (97 осіб жіночої статі та 92 особи чоловічої статі) та віку (6-7-ми річного віку - 50 осіб, 8-ми річного віку - 47 осіб, 9-ти річного віку - 46 осіб, 10-ти річного віку - 46 осіб).

В якості одного із критеріїв соціально-психологічної компетентності молодших школярів у сфері нормовідповідності власної поведінки нами було визначено рівень їх морального розвитку, або розвитку їх моральних суджень. 3 метою конкретизації дослідницької позиції в даному напрямку використаємо найбільш відому моральну дилему із широкого арсеналу моральних дилем методики Л. Колберга - дилему Хайнца [7]. Дилема Хайнца представляє собою гіпотетичну історію, яка пов'язана з таким специфічним моральним аспектом, як цінність людського життя. Після прочитання історії слухачеві задаються наступні питання. Чи повинен був Хайнц красти ліки? Чи змінилось би що-небудь, якби Хайнц не любив свою дружину, або вмираюча людина була йому незнайомою? і т.д.

На підставі відповідей на подібні питання при вирішенні моральної дилеми Хайнца на основі теорії моральних суджень Л. Колберга стало можливим категоризувати рівень морального розвитку молодших школярів. Гіпотетично за Л. Колбергом можна виділити три основні рівні розвитку моральних суджень, кожен з яких складається з двох стадій:

1. Рівень передконвенціональної моралі. Перша стадія даного рівня отримала назву «орієнтація на покарання $i$ слухняність». Друга стадія рівня передконвенціональної моралі «індивідуалізм, інструментальна мета і обмін».

2. Рівень конвенціональної моралі. На рівні конвенціональної моралі третя стадія морального розвитку називається стадією «взаємних міжсособистісних очікувань $i$ відносин», або стадією «хороших хлопчиків $і$ дівчаток». На четвертій стадії рівня конвенціональної моралі - «соціальної системи і совісті»- дитина орієнтується на більш широкі соціальні групи при виборі правил.

3. Рівень постконвенціональної моралі. На п’ятій стадії рівня постконвенціональної моралі «орієнтаиії на соиіальний договір» - людина починає самостійно вибирати принципи, якими буде керуватися у своєму житті. Шоста стадія рівня постконвенціональної моралі - «орієнтація на універсальні етичні принципи».

Ще одним методом аналізу рівня розвитку уявлень молодших школярів про нормовідповідність власної поведінки стало експертне опитування, в рамках якого для аналізу і систематизації отриманих даних було залучено батьків досліджуваних та їх вчителів.Результуючою оцінкою рівня розвитку уявлень про нормовідповідність власної поведінки для кожного молодшого школяра став показник, обчислений як середнє арифметичне значення двох окремих експертних оцінок - одного із батьків та вчителя.

У підсумку співвідношення стадій розвитку моральних суджень молодших школярів за методикою Л. Колберга з одного боку, і рівнів розвитку уявлень про нормовідповідність власної поведінки на основі показників експертного опитування - 3 іншого, ми отримали інтегральний емпіричний показник - рівень розвитку соціально-психологічної компетентності досліджуваних у сфері нормовідповідності власної поведінки. Вимірювався даний показник у порядковій шкалі (низький рівень, середній рівень, високий рівень).

Наступний етап дослідження передбачав вивчення взаємозв'язку між рівнем розвитку соціально-психологічної компетентності молодших школярів у сфері нормовідповідності власної поведінки та показниками їх статі, віку, соціального статусу сім'ї та соціометричного статусу в класі. 3 цією метою було використано метод кростабуляції номінативних ознак (Crosstabs) [2] .

За критерієм статі випробуваних було диференційовано у дві групи - дівчат та хлопців. За віковою ознакою досліджуваних було розподілено у чотири вікові групи: 6-7-ми річні, 8-ми річні, 9- 
ти річні та 10-ти річні школярі. Інформацію щодо соціального статусу сім'ї школяра було отримано на основі даних анкетування батьків, класних керівників та соціальних педагогів закладу освіти. Соціометричний статус досліджуваних в класі визначався за допомогою соціометричного методу Дж. Морено [3].

Результатом соціометричного дослідження стала соціограма - схема на зразок мішені, що дає наочне уявлення про соціометричний статус досліджуваних: ті, хто не отримали жодного вибору; ті, хто отримали менше половини виборів; ті, хто отримали половину або більше виборів; ті, хто отримали максимальну кількість виборів. Отже, за критерієм соціометричного статусу досліджуваних було диференційовано у чотири групи: «ізольовані», «прийняті», «бажані», «зірки».

Проаналізуємо основні закономірності, отримані в рамках вивчення взаємозв’язку між рівнем розвитку соціально-психологічної компетентності молодших школярів у сфері нормовідповідності власної поведінки та показниками їх статі, віку, соціального статусу сім'ї та соціометричного статусу в класі. Кростабуляція частоти зустрічання рівнів розвитку соціально-психологічної компетентності молодших школярів у сфері нормовідповідності власної поведінки 3 частотою зустрічання характеристик їх статі дозволило виявити ряд важливих закономірностей (див. табл. 1).

Таблиця 1

Кростабуляція статі досліджуваних з рівнем їх соціально-психологічної компетентності у сфері нормовідповідності власної поведінки

\begin{tabular}{|c|c|c|c|c|c|}
\hline \multirow{2}{*}{\multicolumn{2}{|c|}{$\begin{array}{l}\text { Критерій диференціації } \\
\text { досліджуваних }\end{array}$}} & \multicolumn{3}{|c|}{$\begin{array}{c}\text { Рівень соціально-психологічної компетентності у сфері } \\
\text { нормовідповідності власної поведінки }\end{array}$} & \multirow{2}{*}{$\mathrm{P}$} \\
\hline & & низький & середній & високий & \\
\hline \multirow{2}{*}{ Стать } & жіноча & 23 & 50 & 23 & \multirow{2}{*}{0,429} \\
\hline & чоловіча & 30 & 43 & 27 & \\
\hline
\end{tabular}

Як свідчать табличні дані, інтерпретація даних кростабуляції частоти зустрічання рівнів розвитку соціально-психологічної компетентності молодших школярів у сфері нормовідповідності власної поведінки з частотою зустрічання характеристик їх статі не представляє наукового інтересу, оскільки рівень статистичної значущості виявлених тенденцій виявився недостовірним $(\mathrm{p}>0,05)$. Такі результати можуть свідчити про відсутність достовірних відмінностей у рівні розвитку соціальнопсихологічної компетентності досліджуваних у сфері нормовідповідності власної поведінки за критерієм статі. Поясненням виявленого факту, на наш погляд, $\epsilon$ те, що молодші школярі мають невеликий життєвий досвід і в силу свого віку вони недостатньо інтегровані в соціум.

Перейдемо до аналізу закономірностей, отриманих в ході вивчення взаємозв'язку між рівнем розвитку соціально-психологічної компетентності молодших школярів у сфері нормовідповідності власної поведінки та показниками їх віку (див. табл. 2 ).

Таблиия 2

Кростабуляція віку досліджуваних з рівнем їх соціально-психологічної компетентності у сфері нормовідповідності власної поведінки

\begin{tabular}{|c|c|c|c|c|c|}
\hline \multirow{2}{*}{\multicolumn{2}{|c|}{$\begin{array}{c}\text { Критерій диференціації } \\
\text { досліджуваних }\end{array}$}} & \multicolumn{3}{|c|}{$\begin{array}{c}\text { Рівень соціально-психологічної компетентності у } \\
\text { сфері нормовідповідності власної поведінки }\end{array}$} & \multirow[t]{2}{*}{$\mathrm{P}$} \\
\hline & & визький & середній & високий & \\
\hline \multirow{4}{*}{ Вік } & 6-7 років & 28 & 19 & 5 & \multirow{4}{*}{0,000} \\
\hline & 8 років & 23 & 17 & 10 & \\
\hline & 9 років & 8 & 27 & 13 & \\
\hline & 10 років & 3 & 22 & 21 & \\
\hline
\end{tabular}

3 огляду на табличні дані, можна констатувати високий рівень статистичної значущості виявленого взаємозв'язку між віком досліджуваних та рівнем розвитку їх соціально-психологічної компетентності у сфері нормовідповідності власної поведінки $(\mathrm{p}<0,001) .3$ високим ступенем 
ймовірності достовірний характер взаємозв'язку між віком молодших школярів та рівнем розвитку їх соціально-психологічної компетентності у сфері нормовідповідності власної поведінки було підтверджено за рахунок частоти розподілу означеної змінної у найстаршій (10 років) і наймолодшій (6-7 років) їх вікових категоріях. Можна відмітити, що серед досліджуваних 10 - річного віку у порівнянні з усіма іншими віковими категоріями молодших школярів спостерігається найбільша частота зустрічання високого рівня розвитку соціально-психологічної компетентності у сфері нормовідповідності власної поведінки. Натомість, у наймолодшій віковій категорії молодших школярів (6-7 років) спостерігаємо зворотній характер взаємозалежності.

Ймовірним поясненням виявлених закономірностей може бути те, що у процесі виховання та соціалізації діти знайомляться із нормами поведінки, стають відповідальнішими. Велика кількість вчених (Павелків Р.В., Скрипченко О.В., Мухіна В.С. та ін.) визнають спадкоємність морального розвитку від дитинства до більш старших вікових періодів і важливість морального впливу оточуючих. На їх думку, якісні зміни відбуваються завдяки ускладненню Я-образу дитини [11].

Проаналізуємо закономірності, виявлені в ході вивчення взаємозв'язку між рівнем розвитку соціально-психологічної компетентності молодших школярів у сфері нормовідповідності власної поведінки та показниками соціального статусу їх сім’ї (див. табл. 3). 3 огляду на табличні дані, можна констатувати високий рівень статистичної значущості виявленого взаємозв'язку між соціальним статусом сім'ї молодших школярів та рівнем розвитку їх соціально-психологічної компетентності у сфері нормовідповідності власної поведінки (p<0,001). Серед досліджуваних 3 високим соціальним статусом сім'ї спостерігається найбільша частота зустрічання високого рівня розвитку соціальнопсихологічної компетентності у сфері нормовідповідності власної поведінки. Натомість, серед досліджуваних з низьким соціальним статусом сім'ї спостерігається найбільша частота зустрічання низького рівня розвитку соціально-психологічної компетентності у сфері нормовідповідності власної поведінки.

Таблиия 3

Кростабуляція соціального статусу сім'ї досліджуваних з рівнем їх соціальнопсихологічної компетентності у сфері нормовідповідності власної поведінки

\begin{tabular}{|c|c|c|c|c|c|}
\hline \multirow{2}{*}{\multicolumn{2}{|c|}{$\begin{array}{c}\text { Критерій } \\
\text { диференціації } \\
\text { досліджуваних }\end{array}$}} & \multicolumn{3}{|c|}{$\begin{array}{l}\text { Рівень соціально-психологічної компетентності } \\
\text { у сфері нормовідповідності власної поведінки }\end{array}$} & \multirow[t]{2}{*}{$\mathrm{P}$} \\
\hline & & низький & середній & високий & \\
\hline \multirow{3}{*}{$\begin{array}{l}\text { Соціальний } \\
\text { статус сім'ї }\end{array}$} & Низький & 27 & 30 & 15 & \multirow{3}{*}{0,000} \\
\hline & Середній & 25 & 40 & 18 & \\
\hline & Високий & 5 & 11 & 25 & \\
\hline
\end{tabular}

Приведемо логічні аргументи для пояснення причин виявлених закономірностей. Для сімей із високим соціальним статусом характерним $є$ високий рівень реалізації функцій сім'ї. Сім’ї з високим соціальним статусом вважаються благополучними, оскільки вони найбільш адаптовані до життя в суспільстві та приділяють увагу моральному вихованню дітей.

Насамкінець, проаналізуємо закономірності, виявлені в ході вивчення взаємозв'язку між рівнем розвитку соціально-психологічної компетентності молодших школярів у сфері нормовідповідності власної поведінки та показниками їх соціометричного статусу в класі (див. табл. 4 ).

Кростабуляціясоціометричного статусу досліджуваних 3 рівнем їх соціально-психологічної компетентності у сфері нормовідповідності власної поведінки

\begin{tabular}{|c|l|c|c|c|c|}
\hline \multirow{2}{*}{$\begin{array}{c}\text { Критерій диференціації } \\
\text { досліджуваних }\end{array}$} & \multicolumn{2}{|c|}{$\begin{array}{c}\text { Pівень соціально-психологічної компетентності у } \\
\text { сфері нормовідповідності власної поведінки }\end{array}$} & \multirow{2}{*}{ P } \\
\cline { 2 - 5 } & низький & середній & високий & \\
\hline \multirow{2}{*}{$\begin{array}{c}\text { Соціометри- } \\
\text { чний статус в } \\
\text { класі }\end{array}$} & ізольовані & 10 & 15 & 7 & \\
\cline { 2 - 5 } & прийняті & 23 & 34 & 21 & \\
\cline { 2 - 5 } & бажані & 14 & 27 & 12 & \\
\cline { 2 - 5 } & зірки & 5 & 5 & 126 \\
\hline
\end{tabular}


3 огляду на табличні дані, можна констатувати, що статистично достовірного взаємозв'язку між рівнем розвитку соціально-психологічної компетентності молодших школярів у сфері нормовідповідності власної поведінки та показниками їх соціометричного статусу в класі виявлено не було (p>0,05). Це може свідчити про те, що підтверджено випадковий характер відмінностей між досліджуваними $з$ різним соціометричним статусом в класі за частотою розподілу рівнів розвитку соціально-психологічної компетентності у сфері нормовідповідності власної поведінки.

Висновки 3 даного дослідження $\mathbf{i}$ перспективи подальших розвідок. Значущість емпіричного дослідження рівня розвитку соціально-психологічної компетентності молодших школярів у сфері нормовідповідності власної поведінки важко переоцінити. Психологічний зміст роботи з морального становлення особистості молодших школярів полягає в тому, щоб допомагати їм просуватися від елементарних навичок поведінки до більш високого рівня, де потрібні самостійність ухвалення рішень і моральний вибір.

\section{Список використаних джерел}

1. Борищевський М. Й. Психологія самоактивності учнів у виховному процесі : навч.-метод. посіб. / М. Й. Борищевський, С. Т. Музичук, В. В. Антонечко ; Ін-т змісту і методів навчання ; Ін-т психології ім. Г. С. Костюка АПН України. - Київ, 1999. - 190 с.

2. Бююль A. SPSS: искусство обработки информации: анализ статистических данных и восстановление скрытых закономірностей : пер. с нем. / А. Бююль, П. Цёфель. - СПб. : ООО «ДиаСофтЮГ», 2002. - 608 с.

3. Корнєв М. Н. Соціальна психологія : підручник / М. Н. Корнєв, А. Б. Коваленко. - Київ, 1995. $-304 \mathrm{c}$.

4. Лупінович С. М. Формування ціннісного ставлення до навчання в учнів молодших класів школи - комплексу естетичного виховання : дис. ... канд. пед. наук : 13.00.07 / С. М. Лупінович ; Терноп. нац. пед. ун-т ім. В. Гнатюка. - Тернопіль, 2006. - 240 с.

5. Мишкова Г. А. Психологические особенности проявлений нравственности младших школьников, воспитывающихся в различных социально-педагогических условиях : дис. ... канд. психол. наук : 19.00 .07 / Г. А. Мишакова. - Самара, 2010. - 227 с.

6. Мухина В. С. Возрастная психология: феноменология развития, детство, отрочество : учеб. для студентов вузов / В. С. Мухина. - 9-е изд., стереотип. - М. : Академия, 2004. - 456 с.

7. Орбан-Лембрик Л. Е. Соціальна психологія : підручник : у 2 кн. Кн. 1. Соціальна психологія особистості і спілкування / Л. Е. Орбан-Лембрик. - Київ : Либідь, 2004. - 576 с.

8. Павелків Р. В. Розвиток моральної свідомості та самосвідомості в молодшому шкільному віці : дис. ... д-ра психол. наук : 19.00.07 / Р. В. Павелків. - Рівне, 2005. - 455 с.

9. Порохняк Д. С. Вікові особливості морального розвитку молодших школярів / Д. С. Порохняк // Збірник наукових праць КПНУ імені Івана Огієнка / Ін-т психології імені Г. С. Костюка НАПН України. - 2014. - Вип. 25. - С. 393-403.

10. Скрипченко О. В. Психолого-педагогічні основи навчання / О.В. Скрипченко, О. С. Падалка, Л. О. Скрипченко. - вид. 2-ге, допов. - Київ : Укр. центр дух. культури, 2005. - 710 с.

11. Струманський В. П. Виховна робота в національній школі / В. П. Струманський. - Київ : I3MH, 1997. $-184 \mathrm{c}$.

\section{References}

1. Boryshchevskyi M. Y. Psykholohiia samoaktyvnosti uchniv u vykhovnomu protsesi : navch.metod. posib. / M. Y. Boryshchevskyi, S. T. Muzychuk, V. V. Antonechko; In-t zmistu i metodiv navchannia ; In-t psykholohii im. H. S. Kostiuka APN Ukrainy. - Kyiv, 1999. - 190 s.

2. Biuiul A. SPSS: yskusstvo obrabotky ynformatsyy: analyz statystycheskykh dannыkh y vosstanovlenye skrыtыkh zakonomernostei : per. s nem. / A. Biuiul, P. Tsëfel. - SPb. : OOO «DyaSoftIuH», 2002. $-608 \mathrm{~s}$.

3. Korniev M. N. Sotsialna psykholohiia : pidruchnyk / M. N. Korniev, A. B. Kovalenko. - Kyiv, 1995. $-304 \mathrm{~s}$.

4. Lupinovych S. M. Formuvannia tsinnisnoho stavlennia do navchannia v uchniv molodshykh klasiv shkoly - kompleksu estetychnoho vykhovannia : dys. ... kand. ped. nauk: 13.00.07 / S. M. Lupinovych ; Ternop. nats. ped. un-t im. V. Hnatiuka. - Ternopyl’, 2006. - 240 s.

5. Myshakova H. A. Psykholohycheskye osobennosty proiavlenyi nravstvennosty mladshykh shkolnykov, vospytыvaiushchykhsia v razlychnыkh sotsyalno-pedahohycheskykh uslovyiakh : dys. ... kand. psykhol. nauk : 19.00.07 / H. A. Myshakova. - Samara, 2010. - 227 s. 
6. Mukhyna V.S. Vozrastnaia psykholohyia: fenomenolohyia razvytyia, detstvo, otrochestvo : ucheb. dlia studentov vuzov / V. S. Mukhyna. - 9-e yzd., stereotyp. - M. : Akademyia, 2004. - 456 s.

7. Orban-Lembryk L. E. Sotsialna psykholohiia : pidruchnyk : u 2 kn. Kn. 1. Sotsialna psykholohiia osobystosti i spilkuvannia / L. E. Orban-Lembryk. - Kyiv : Lybid, 2004. - 576 s.

8. Pavelkiv R. V. Rozvytok moralnoi svidomosti ta samosvidomosti v molodshomu shkilnomu vitsi : dys. ... d-ra psykhol. nauk : 19.00.07 / R. V. Pavelkiv. - Rivne, 2005. - 455 s.

9. Porokhniak D. S. Vikovi osoblyvosti moralnoho rozvytku molodshykh shkoliariv / D. S. Porokhniak // Zbirnyk naukovykh prats KPNU imeni Ivana Ohiienka / In-t psykholohii imeni H. S. Kostiuka NAPN Ukrainy. - 2014. - Vyp. 25. - S. 393-403.

10. Skrypchenko O. V. Psykholoho-pedahohichni osnovy navchannia / O. V. Skrypchenko, O. S. Padalka, L. O. Skrypchenko. - vyd. 2-he, dopov. - Kyiv : Ukr. tsentr dukh. kultury, 2005. - 710 s.

11. Strumanskyi V. P. Vykhovna robota v natsionalnii shkoli / V. P. Strumanskyi. - Kyiv : IZMN, 1997. $-184 \mathrm{~s}$.

\section{S. Khomych CHARACTERISTICS OF JUNIOR SCHOOL STUDENTS' SOCIAL AND PSYCHOLOGICAL COMPETENCE IN THE ACCORDANCE WITH OWN BEHAVIORAL NORMS}

The study has revealed scholars' research that outlined the issue of moral development. Basing on the theory studies it has been proved that child's behavior in accordance with norms has been defined with the help of moral manners. Its indicators have been presented with personal moral characteristics developed through the conscious knowledge obtaining dealing with the moral norms. The research has given the results of experimental research of the level of school students' social and psychological competence development in the accordance with own behavioral norms depending on their gender, age, family social and economic position, and sociometric position in a class. On the one hand with the help of development stage correlation of junior school students' moral judgment according to L.Kohlberg's methodology, and on the other hand, development levels about the ideas of the own behavioral norms accordance basing on expert poll the author has obtained integral empirical indicator presented as the level of social and psychological competence development of researched ones in the accordance with own behavioral norms.

The study has concerned with the special features connection of the level of junior school students' social and psychological competence development in the accordance with own behavioral norms and indicators of their gender, age,family social and economic position, and sociometric position in a class.

Key words: junior school student, moral judgment, social and psychological competence, accordance of behavioral norms, gender, age, family social and economic position, sociometric position in a class.

УДК 159.9:615.851

Р. П. ШЕВЧЕНКО

DOI: https://doi.org/10.35619/prap_rv.vi12.79

\section{СУБДЕПРЕССИВНОЕ СОСТОЯНИЕ У СТУДЕНТОВ ВЫСШИХ УЧЕБНЫХ ЗАВЕДЕНИЙ СПЕЦИАЛЬНОСТИ МОРСКОГО И РЕЧНОГО ТРАНСПОРТА}

Стаття присвячена огляду наукової літератури, вивченню стану депресії у моряків, а також представлено результати проведеного дослідження міри вираженості особливостей депресивного стану у студентів вищих навчальних закладів спеціальності річкового та морського транспорту. Дослідження проведене за допомогою методів спостереження, бесіди, методики Шкала Цунга для самооиінки деnресії (Zung Self-Rating Depression Scale), адаптований при відділенні наркології НДІ ім. Бехтєрєва T.I. Балашовою. Виявлено, що студенти молодших курсів частіше, аніж студенти старших курсів, виявляють стан підвищеного настрою, впевненості у позитивних життєвих перспективах, надії на майбутнє, рідме зазнають стану немотивованої тривоги. У них частіше спостерігається стан депресії ситуативного або невротичного тенезу. Субдепресивний стан та елементи замаскованої депресї̈ було виявлено у студентів старших курсів, щео сигналізує про необхідність розробки для даної категорії опитаних системи психокорекиійної допомоги для вироблення стійких рис, які дозволили би протидіяти стресогенним чинникам, щзо впливають на них у період тривалого плавання, збереження позитивного життєвого тонусу та психічного здоров'я загалом.

Ключові слова: субдепресивний стан, порушення адаптаиї̈, розлади емочійної сфери, психокорекиія, психологічний супровід. 